\title{
Low, T. 2014. Where Song Began: \\ Australia's birds and how they changed the world. Melbourne, Australia: Viking
}

In Where Song Began, Tim Low tells us that he decided to write the book because of one opposite of song: silence; the silence of the ornithological community about the recent revolution in our understanding of birds.

For most of the Twentieth Century, it was believed that birds originated in Europe. There was good reason for this: the oldest known bird, which looked much like a dinosaur, is Archaeopteryx lithographica, described by Meyer in 1861. It lived in Germany during the Jurassic, 150 million years ago and no older, uncontestable bird fossils have ever been found.

In the last decades, however, fossil and genetic evidence has pointed towards a long and complex evolutionary history of birds in the Southern hemisphere. Low believes that the scientific community has been too slow in adapting its views to the new evidence, and he is probably quite right. His book reviews the evolution, biogeography, ecology, ethology and conservation of birds, with emphasis in Australia, but with frequent comparison with other parts of the world.

Birds cannot be properly understood if you just keep in mind the world of today, so different from the world of 100 million years ago where biogeographic reconstruction shows that birds could fly along continuous rainforest from New Guinea to Tasmania (see MongeNájera, 1996). New Zealand is a good example of huge historical change in bird communities. Once, billions of marine birds nested there, but -according to Low- adaptation to life in the sea led them to extinction. Sea-adapted feet and wings prevent seabirds from nesting on trees:

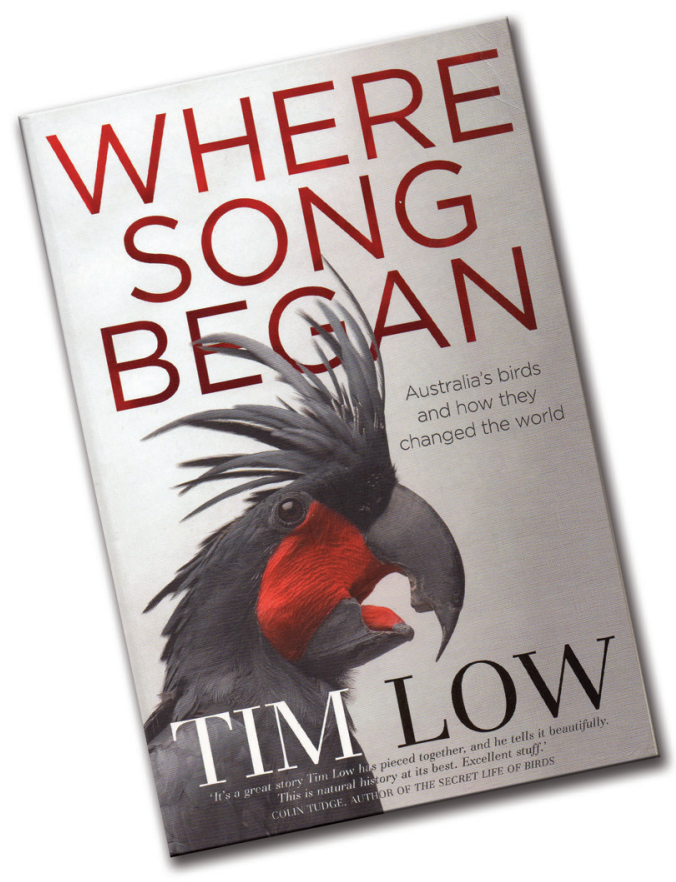

chicks only survive in habitats that are free of the advanced mammal predators that can easily capture them in ground nests. When humans introduced such predators to New Zealand and other islands, many seabird populations came to an end.

Additionally, to the history of birds, Low summarizes much information into a neat model of local ecology: the ecology of arid Australia. Australia appears to be defined by its poor soil and many hours of solar exposure. The result: a strong photosynthetic production of carbohydrates that accumulate in barks, leaves, fruits and flowers. With no advanced mammals, nectarivorous birds became abundant, large 
and aggressive. Nevertheless, life is hard for plants on poor soils: they could not develop the Nitrogen-based anti-herbivore toxins of other lands. Australian plants rely on Carbon-based phenols, aromatic oils and strangely, crypsis and mimicry. How is this possible? Because bird olfaction is often weak and some plant species are successfully protected by looking dead, inedible or something else altogether. Neotropical plants cannot get away with this trick because the ever present mammal herbivores would smell it.
In the book I learned that penguins do not run away from fire, thus facing the same danger that deeply affects Australian plants: getting burned. When you have abundant biomass, a dry environment and heat, fires can become frequent and devastating: mutations that help them cope with fire have been fixed in many Australian plants, including the development of specialized seeds.

Seeds with abundant food reserves and strong protective walls are big and need appropriately large dispersers. With few mammal

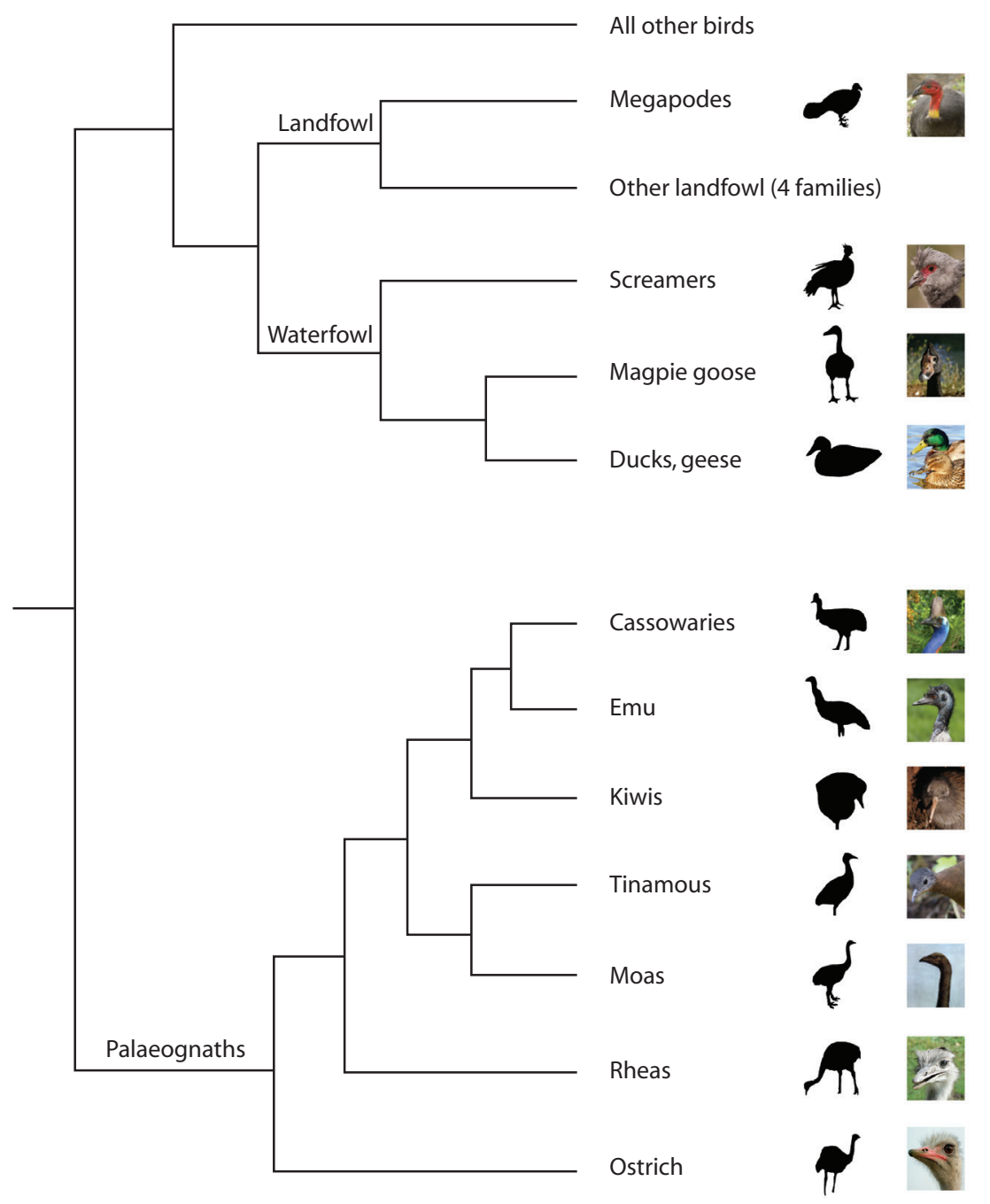

Fig. 1. Evolutionary relationships of living birds as summarized in Low 2014. Photographs: Gallie, L; Hats, L; Kennedy, T; Kniesel, A; Law, K; Lodge, G; Maugatautari Ecological Island Trust; Nunn, V; Smith, R; Svensson, K; Van der Well, S; Warby, W. (Wikicommons.com). Image compilation by Priscilla Carbonell. 
options, birds occupied the niche, and just like what happened to the Neotropical seasonal forest, Australian ecosystems lost many megafaunal dispersers after the Pleistocene, reducing the dispersal capacity of many plants. Nevertheless, we still see a good example of how the system operated in the best Pleistocene years: the extraordinary cassowary, Casuarius spp. a non flying $80 \mathrm{~kg}$ disperser with dangerous $12 \mathrm{~cm}$ long claws and a mysterious head "casque" with a yet unproven function.

The final part deals with a key part of the book, its title: where did bird songs began? The British imported songbirds to Australia in 1862 because they thought the local species were not musical enough. However, we now know that some Australian species produce extraordinarily loud and complex songs. These are species that branched early in the cladogram of birds, like lyrebirds and scrub-birds (Fig. 1), and Low suggests that early songbirds ate leaves and were similar to them.

He fails to mention, though, relevant publications in this field, including one from his own country: Australian philosopher Graham Pont's work on bird and human music (Pont 1998, 2013), as well as my own list of 31 characteristics shared by bird calls and human music (Monge-Nájera 1998) and recent arguments against the musicality of bird songs (Araya-Salas, 2012). Besides, ignoring relevant literature, Low occasionally supports his interpretations with personal anecdotes that seem forced into the text; yet overall the book is well documented with scientific references and the author can be excused for missing some papers that could have updated and generally improved the book.

Like Hitchcock's film The Birds, some Australian birds attack people, peck their eyes and even kill, but despite mentioning these problems, Low criticizes how we humans treat birds, which feel anxiety, fear and pain just as we do. He reminds us that, according to some experiments, several bird species can outsmart many mammals. Even when we try to do good by providing shelter and food for them, we end up hurting some bird species: there is no easy solution to this complex problem of avianhuman interactions.

The book is addressed to Australian readers, forcing you to get online to find out who May Gibbs was or to identify antipodean sites and species, but certainly Where Song Began is worth reading and summarizes a large mass of recent scientific literature of general interest to professional and amateur ornithologists.

I particularly liked the way Low explains how scientists tend to show their human weaknesses more clearly when reliable data are hard to obtain, as is the case of bird-related phenomena that happened well before science existed. Quite unscientifically, even the best researchers can cling to their pet hypotheses, forgetting that our function is not to prove ourselves right, but trying to do the opposite.

The book has a seabird section of obvious literary value and is seeded with many ecological insights that should inspire tropical biologists to go and test them in the field. You can order it for about US\$24, plus shipping, from Viking Press, Melbourne, Australia (www.penguin.com.au).

\section{REFERENCES}

Araya-Salas, M. (2012). Is birdsong music? Evaluating harmonic intervals in songs of a Neotropical songbird. Animal Behaviour 84, 309-313.

Monge-Nájera, J. (1996). Jurassic-Pliocene biogeography: testing a model with velvet worm (Onychophora) vicariance. Revista de Biología Tropical 44(1), 159-175.

Monge-Nájera, J. (1998). Comparison of bird calls and human music: an evolutionary approach. In J. Monge-Nájera. (Editor). Orígenes de la Música y la Biomusicología. San José, Costa Rica: Universidad Estatal a Distancia.

Pont, G. (1998). The origin of music: new light on an old hypothesis. In J. Monge-Nájera. (Editor). Orígenes de la Música y la Biomusicología. San José, Costa Rica: Universidad Estatal a Distancia.

Pont, G. (2013). From Birdsong to Babel: the canine connection in the origin of human language. UNED Research Journal 5(1), 11-16.

Julián Monge-Nájera

Revista de Biología Tropical•julianmonge@gmail.com 
